\title{
Trace Metal Determination in Herbal Plants by Acid Digestion From Jeddah Market in Saudi Arabia
}

\author{
Basma G. Alhogbi \\ Correspondence: Basma G. Alhogbi, Department of Chemistry, King Abdulaziz University, Jeddah, Saudi Arabia. \\ Email: balhogbi@kau.edu.sa, alhogbib@gmail.com
}

Received: March 24, 2018 Accepted: May 14, 2018 Online Published: June 3, 2018

doi:10.5539/ijc.v10n3p8

URL: https://doi.org/10.5539/ijc.v10n3p8

\begin{abstract}
The world is facing a serious issue with plants contaminated by trace metals. Therefore, a consideration is required due to its danger that impacts both humans and animals. Herbs are extensively used worldwide for their seasoning and therapeutic properties. This study aimed to estimate the level of trace metals ( $\mathrm{Fe}, \mathrm{Zn}, \mathrm{Pb}, \mathrm{Cr}, \mathrm{Cu}, \mathrm{Ni}$ ) in selected customary herbs consumed in Saudi Arabia. The 5 samples of herbs were purchased from a local market in Jeddah City (Mint (Mentha), Basil (Ocimum), Arugula (Eruca sativa), Coriander (Coriandrum sativum) and Parsley (Petroselinum crispum)). Acid digestion was applied to the plant leaves and trace metals concentrations were determined using Inductively Coupled Plasma - Optical Emission Spectroscopy (ICP-OES). Metals were observed to be available in varied concentrations in the herb plant samples. The highest metal values, especially in Arugula (ES) $218.3 \pm 1.9 \mathrm{mg} / \mathrm{kg}$ and $24.4 \pm 0.09 \mathrm{mg} / \mathrm{kg}$ for $\mathrm{Zn}$ and $\mathrm{Ni}$ respectively, $\mathrm{Cr}$ was under detection limit, Coriander $(\mathrm{CS}) 148.5 \pm 1.8 \mathrm{mg} / \mathrm{kg}$ and $17.3 \pm 0.07 \mathrm{mg} / \mathrm{kg}$ for Fe and $\mathrm{Pb}$ respectively, Mint (ME) $28.6 \pm 0.26 \mathrm{mg} / \mathrm{kg}$ for $\mathrm{Cu}$, while Basil (OC) was recorded below the (WHO) permissible limits $18.9 \pm 0.06 \mathrm{mg} / \mathrm{kg}$ and $1.1 \pm 0.003 \mathrm{mg} / \mathrm{kg}$ for $\mathrm{Zn}$ and $\mathrm{Cr}$ respectively, besides all metals were higher than the (WHO) allowed limit in Parsley (PC). The study found that most of the examined herbs contained hazardous levels of trace metals that exceeded the World Health Organization (WHO) permissible limits.
\end{abstract}

Keywords: herbal plants, trace metals, acid digestion, determination, ICP-OES

\section{Introduction}

Heavy metals found in trace amounts in plants, which has a biological effect can be toxic to plants and human being through the food chain. In this report the term "trace metals" will be for these possible phytotoxic elements (Rascio and Navari-Izzo, 2011). The most significant sources of trace metals in the nature are the anthropogenic activities, for example mining, steel, iron or chemical industry, smelting method, traffic, farming as well as domestic activities (Suciu et al., 2008). Plants have ability to absorb and accumulate xenobiotic can be helpful markers of environmental contamination ( Farago, 1994; Pandolfini et al., 1997).

There are 14 mineral elements are required for the plants in their full physiological activity. Depending on the element, the range of concentration is from $10,000 \mathrm{mg} / \mathrm{kg} \geq 0.001 \mathrm{mg} / \mathrm{kg}$ (Wheal et al., 2011). Every nutrient element is essential within an ideal range. If this range exceeded the possible results may vary from changes in many physiological processes occurring at the cellular/ molecular level such as disabling enzymes, blocking functional groups of metabolic important molecules, substituting essential elements or disrupting the integrity of the membrane (Rascio and Navari-Izzo, 2011). Herbal plants represent an important class of various traditional medicine systems and, in recent years, they are increasingly used in the primary health care intervention in both developed and developing countries. Herbal medicines are extensively used for the treatment of numerous illnesses. They are frequently containing highly effective pharmacological components, including minerals and trace metals (Fabricant and Farnsworth, 2001).

In parallel with the increasing attention of the therapeutic benefits of herbal plants, there is a high concern about the safety and poisonous of natural herbs and formulation given out in the market. There is a widespread misconception that natural herbs and plants are inherently safe. Nevertheless, there has been a large volume of reports on incidences of toxicity and adverse effects linked to the use of herbal plants and their formulations in different parts of the world (AlBraik et al., 2008). The toxicity of herbal plants may relate to contaminants in soil and water such as pesticides, microbes, and chemical toxins also transportation and storage can affect the quality of herbs due to contaminant air (Ernst, 2002; Saad et al., 2006 ). The toxicity of trace metals on human health and the environment has attracted considerable attention in recent years. Plants are the main link in the transferring the trace metals from the contaminated soil to humans through the food chain. Trace metals have low excretion rates through the kidney which could result in 
damaging effects on humans even at very low concentrations. The essential nutrient metals are $\mathrm{Zn}, \mathrm{Co}, \mathrm{Fe}$, and $\mathrm{Cr}$, they are important for the physiological and biological functions of the human body. However, an increase in their intake above certain permissible limits can become toxic (Korfali et al., 2013). In general, several health problems were linked to excessive uptake of dietary trace metals including a decrease in immunological defenses, cardiac dysfunction, fetal malformation, impaired psychosocial and neurological behavior, gastrointestinal cancer, and many others (Singh et al., 2011; Mahan et al., 2017). Various examination have demonstratd the trace metal contamination of herbel, vegetabls plants and canned fruits collected from market or farms in Saudia Arabia and different countries (Al-Hammad and Abd El-Salam 2016; Maghrabi, 2014; Ali, and Al-Qahtani, 2012; Kananke et al., 2014; Begumi et al., 2017; Dghaim et al., 2015; Massadeh \& Al-Massaedh, 2018).

Hence, many techniques were applied for elemental analysis. The most widely recognized strategies utilized nowadays for determining the trace elements in ecological samples include very sensitive spectroscopic methods, for example, inductively coupled plasma-optical emission and mass spectrometry (ICP-OES) and (ICP-MS) in addition to atomic absorption spectroscopy (FAAS, ETAAS) (Wheal et al.; 2011). The utilized sample digestion methods are performed by fusion or wet procedure of heating acid mixtures. Various types of heating systems can be utilized, for example, hot plate, sand bath, aluminum blocks and digestion pressure bomb (Altundag and Tuzen, 2011). There is little information available on the safety of traditional herbs and their production seller in the Saudi Arabia market. This study aims to determine the level of trace metals in some commonly consumed herbs; they were purchased from local market in Jeddah City to assess their relative safety and potential health risk based on the World Health Organization standard limits (WHO, 2011; Onder et al., 2007).

\section{Material and Methods}

\subsection{Sample Collection and Preparation}

Six samples of each of the different five herbal Plants, which are Mint (Mentha), Basil (Ocimum), Arugula (Eruca sativa), Coriander (Coriandrum sativum) and Parsley (Petroselinum crispum) were collected in December 2016 from local market in Jeddah City, Saudi Arabia (Table 1). First, the plant samples were washed with tap water for removing all dust and impurities until it became cleaned as the last wash was by distilled water. The second step was drying samples at room temperature for few days. Finally, the dried plants were grinding using a grinder and stored in plastic bags.

Table 1. Local and botanical name of the herbs and their code

\begin{tabular}{lllll}
\hline Local name & Botanical name & Code & Parts analyzed \\
\hline Mint & Mentha & $M E$ & Leaves \\
Basil & Ocimum & OC & Leaves \\
Arugula & Eruca sativa & ES & Leaves \\
Coriander & Coriandrum sativum & $C S$ & Leaves \\
Parsley & Petroselinum crispum & $P C$ & Leaves \\
\hline
\end{tabular}

\subsection{Acid Digestion Procedures}

$0.5 \mathrm{~g}$ of each plant sample was digested in $50 \mathrm{ml}$ beaker and then $8 \mathrm{ml}$ of concentrated Nitric acid $\mathrm{HNO}_{3}\left(\mathrm{PanReac}^{65 \%}\right)$ was added, covered with a watch glass and left overnight at room temperature in a fume cupboard. $2 \mathrm{ml}$ of $\mathrm{H}_{2} \mathrm{O}_{2}$ (Sigma-Alorich $30 \%)$ was added in the second day and heated on a hot plate $\left(90{ }^{\circ} \mathrm{C}-100\right)$. When the mixture was nearly dry, $5 \mathrm{ml}$ of distilled water was added and covered to continue the heating process until a light yellowish color fume is produced. $5 \mathrm{ml}$ of deionized water was added and left to cool. The samples were filtered with a hardness filter paper No. 2 Whatman and placed in a $50 \mathrm{ml}$ volumetric flask filled up to the mark with $0.1 \mathrm{M}$ Nitric acid and kept for analysis (Maghrabi, 2014).

\subsection{Sample Analysis}

Inductively Coupled Plasma - Optical Emission Spectroscopy (ICP-OES) - Perkin Elmer model 7000 DV) was used for analysis of trace metals concentration such as $\mathrm{Fe}, \mathrm{Cu}, \mathrm{Zn}, \mathrm{Pb}, \mathrm{Ni}$ and $\mathrm{Cr}$ in digested plant samples. The parameters of ICP-OES were wet plasma aerosol type of axial view, nebulizer start-up instant condition, flow rate $(\mathrm{Ar}) 15 \mathrm{~L} / \mathrm{min}$, auxiliary flow (Ar) $0.2 \mathrm{~L} / \mathrm{min}$, nebulizer flow (Ar) $0.8 \mathrm{~L} / \mathrm{min}$, sample uptake rate $1.5 \mathrm{~mL} / \mathrm{min}$, and sample flush time 5 Sec. The wavelengths used for observed elements were $206.2 \mathrm{~nm}$ for $\mathrm{Zn}, 259.94 \mathrm{~nm}$ of $\mathrm{Fe}, 324.75 \mathrm{~nm}$ of $\mathrm{Cu}, 217 \mathrm{~nm} \mathrm{~Pb}$, $231.6 \mathrm{~nm} \mathrm{Ni}$, and $283.56 \mathrm{~nm}$ of $\mathrm{Cr}$. The trace metals concentration was the mean of triplicate readings $\pm \mathrm{SD}$ of the dry sample. The instrument is daily calibrated using the Merck standard solution to build up trust in the precision, reproducibility as data validation. The following formula was used for calculation. 


$$
\operatorname{Metals}(\mathrm{mg} / \mathrm{kg})=\frac{[\text { Conc. of metals }(\mathrm{mg} / \mathrm{kg}) \times \text { Volume of sample }(\mathrm{L})}{[\text { Sample weight }(\mathrm{kg})]}
$$

The contamination factor (CF) was used in the literature for assessment the pollution (Hakanson, 1980; Wang et al., 2015; Nouri, and Haddi, 2016)). The calculation of CF was from the ratio of the concentration in herbal plant $\left(\mathrm{C}_{\text {sample }}\right)$ divided to the background $\left(\mathrm{C}_{\text {background }}\right)$ obtained based on the permissible limit of the metal in the plant by World Health Organization Recommended (WHO) (WHO, 2011). The classification of CF values stated by Hakanson (1980) is: CF<1 entitles low pollution factor, $1 \leq \mathrm{CF}<3$ moderate pollution factor, $3 \leq \mathrm{CF}>6$ is considered a pollution factor, $\mathrm{CF} \geq 6$ is an abundant pollution factor.

$$
\mathrm{CF}=\frac{\mathrm{C}_{\text {sample }}}{\mathrm{C}_{\text {background }}}
$$

\subsection{Statistical Analysis}

The mean concentration was subjected to statistical analysis using one-way ANOVA, to test the difference between trace elements in the tested herbal plants, also the Post Hoc tests were applied to measure the significant different between the trace elements for each two elements (significance $P<0.05$ ), using the (SPSS 18.0, USA) and Microsoft Excel 2013 software packages.

\section{Results and Discussion}

The average concentrations of $\mathrm{Fe}, \mathrm{Cu}, \mathrm{Zn}, \mathrm{Pb}, \mathrm{Ni}$. and $\mathrm{Cr}$ in Parsley (PC), Arugula (ES), Coriander (CS), Mint (ME) and Basil (OC) herbal plants collected from different local market in Jeddah City are shown in (Figure 1) compared with the World Health Organization (WHO) recommended values. The arrangement order of trace metal in the herbal plants was found as in this sequence of $\mathrm{Zn}>\mathrm{Fe}>\mathrm{Ni}>\mathrm{Cu}>\mathrm{Pb}>\mathrm{Cr}$.

Fe concentration in the herbal plants samples in this study shows a range of values from $44.4 \pm 0.15 \mathrm{mg} / \mathrm{kg}$ to $148.5 \pm 1.8$ $\mathrm{mg} / \mathrm{kg}$ as shown in (Figure 1). Moreover, the Fe amount in almost all plant samples is above the permissible limit prescribed by WHO $(20 \mathrm{mg} / \mathrm{kg})$. Fe is a standout element amongst the critical components those are essential to the human body for purpose of oxygen rotation in the blood. Lack of Fe can cause different sorts of illnesses. However, the growth of plants can be affected by high amount of Fe element. The recorded amount of Fe in these herbal plants compared with the amounts of $\mathrm{Fe}$ found in Egyptian spices and medicinal plants are ranged between $26.96 \mathrm{mg} / \mathrm{kg}$ and $1046.25 \mathrm{mg} / \mathrm{kg}$, while leafy vegetable in Saudi Arabia were found $543.2 \mu \mathrm{g} / \mathrm{g}$ and $399.1 \mu \mathrm{g} / \mathrm{g}$ (Abou-Arab and Abou Donia, 2000; Ali and Al-Qahtan, 2012). The clarification of this circumstance is that the uptake of Fe can be aggregated in the leaves, which considered nutrition manufactures within the plants.

The concentration of $\mathrm{Zn}$ is $18.9 \pm 0.08 \mathrm{mg} / \mathrm{kg}$ in $\mathrm{OC}$ and $218.3 \pm 1.9 \mathrm{mg} / \mathrm{kg}$ in ES. In the other herbal plants $\mathrm{Zn}$ concentration is about of $57 \pm 0.06 \mathrm{mg} / \mathrm{kg}$, which is slightly above the permissible limit reported by WHO $(50 \mathrm{mg} / \mathrm{kg})$. However, zinc is an essential trace element in human diet; also, $\mathrm{Zn}$ is necessary for proper growth, and protein and DNA synthesis (Ogundele et al., 2015). Little information is available on Zn's toxicity; however, high zinc intake beyond permissible limits produces toxic effects on the immune system, blood lipoprotein levels (Ulla et al., 2012). The results agree with the study obtained by Al-Hammad and Abd El-Salam (2016) for Zn level in leafy green $(57.50 \mathrm{mg} / \mathrm{kg})$ in Al-Kharj region, Saudi Arabia (Al-Hammad and Abd El-Salam, 2016).

The concentration range of $\mathrm{Cr}$ metal in the herbal plants samples is from $4.7 \pm 0.08 \mathrm{mg} / \mathrm{kg}$ to not-detectable in ES, as shown in (Figure 1) while ME, CS, OC and PC are $2.3 \pm 0.002 \mathrm{mg} / \mathrm{kg}, 2.1 \pm 0.003 \mathrm{mg} / \mathrm{kg}, 1.1 \pm 0.003 \mathrm{mg} / \mathrm{kg}$, and $4.7 \pm 0.08$ $\mathrm{mg} / \mathrm{kg}$, respectively. The $\mathrm{Cr}$ level is found to be higher than the allowable level which is $1.30 \mathrm{mg} / \mathrm{kg}$ according to WHO recommendation. The high $\mathrm{Cr}$ concentration in the herbs might be a result of distinctive of different species $\left(\mathrm{Cr}^{3+}\right.$ and $\mathrm{Cr}^{6+}$ ) which are coming from varies natural origin and anthropogenic activities. $\mathrm{Cr}$ is non-essential and toxic element for plants and is unfavourable to their development and growth. $\mathrm{Cr}$ was not detected in ES, OC due to the mostly low uptake of $\mathrm{Cr}$ by plants. The mean concentration of $\mathrm{Cr}$ determined in Al-Kharj region, Saudi Arabia in the herbal plants is found $(0.195 \mathrm{mg} / \mathrm{kg}-0.431 \mathrm{mg} / \mathrm{kg}$ ) which is lower than the presented study (Al-Hammad and Abd El-Salam 2016). (Ali, and Al-Qahtani, 2012).

The mean concentration of $\mathrm{Pb}$ in herbal plants samples varied widely from $9.3 \pm 0.31 \mathrm{mg} / \mathrm{kg}-17.3 \pm 0.07 \mathrm{mg} / \mathrm{kg}$, which is higher than the permissible level $(2 \mathrm{mg} / \mathrm{kg}$ ) recommended by WHO. Pb metal is well known as a non-essential toxic for human accumulating in the body, it causes many health problems such as, nervous and immune system problems and learning deficiencies for children, also it is considered as carcinogenic accumulating element (Kananke et al., 2014). $\mathrm{The} \mathrm{Pb}$ toxicities are found in large amounts in many electronic devices and vehicular emissions, which can end up in 
soil and deposit on the leaves through the atmosphere (Nouri, and Haddioui, 2016). Ali and Al-Qahtani (2012) studied different vegetables gathered from fundamental urban communities in the Kingdom of Saudi Arabia reported that $\mathrm{Pb}$ concentrations is $(0.54 \mu \mathrm{g} / \mathrm{mg}-6.98 \mu \mathrm{g} / \mathrm{mg})$ (Ali, and Al-Qahtani, 2012).

The mean concentration of $\mathrm{Ni}$ metal in herbal plants varied between $12.6 \pm 0.04 \mathrm{mg} / \mathrm{kg}-24.4 \pm 0.09 \mathrm{mg} / \mathrm{kg}$. The permissible limit of Ni by WHO is $10 \mathrm{mg} / \mathrm{kg}$, all the concentration values were higher than the recommended limit. $\mathrm{Ni}$ has been thought to be a fundamental element for human and creature health problems and furthermore retained effectively and quickly by plants (Ogundele et al., 2015). The highest mean concentration of Ni in the herbal plants found for this work is higher contrast with high mean concentration of Ni stated in Al-Kharj region, Saudi Arabia (5.28 $\mathrm{mg} / \mathrm{kg}$ ) (Al-Hammad and Abd El-Salam, 2016). On the other hand, in Morocco reported higher amount of Ni $(85 \mathrm{mg} / \mathrm{kg})$ than this work (Al-Jaboobi et al., 2014).

Copper $(\mathrm{Cu})$ metal occurs generally in soil, sediments and air is a micro element, which is essential for the plant metabolism and growth. The concentration of $\mathrm{Cu}$ in herbal plants ranged between $15.4 \pm 0.06 \mathrm{mg} / \mathrm{kg}$ to $28.6 \pm 0.26 \mathrm{mg} / \mathrm{kg}$ (Figure 1), which is higher than the permissible limit according to WHO standard $(10 \mathrm{mg} / \mathrm{kg})$. This agrees with the study carried out by (Ali and Al-Qahtani, 2012) in Saudi Arabia as mentioned previously.

Figure 2 shows the contamination factor (CF) in herbal plant samples. The CFs values were 2.54, 1.86, 1.74, 1.78 for $\mathrm{Cu}$, $\mathrm{Ni}, \mathrm{Cr}$, $\mathrm{Zn}$ respectively, indicating that the herbal plants have a moderate degree of pollution. The value of $\mathrm{CF}$ for $\mathrm{Pb} 8.65$ and Fe 7.42 in herbal plant, which are higher than 6 indicate a high degree of pollution. This outcome indicates that high levels of trace metals in herbal plants can lead to human health risk, moreover a study located in Sri Lanka found similar results with green vegetables collected from their local market (Kananke et al., 2014). Previous study has revealed that the plants of polluted area had high levels of metals compared with the non-polluted area (Magaji et al., 2018).

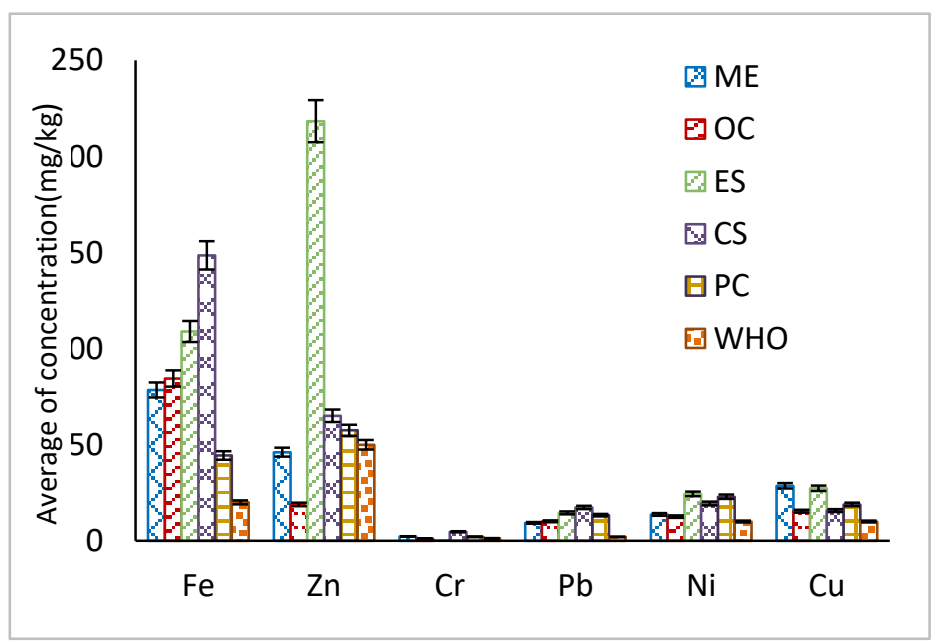

Figure 1. Average concentration of trace metals in herbal plants, WHO

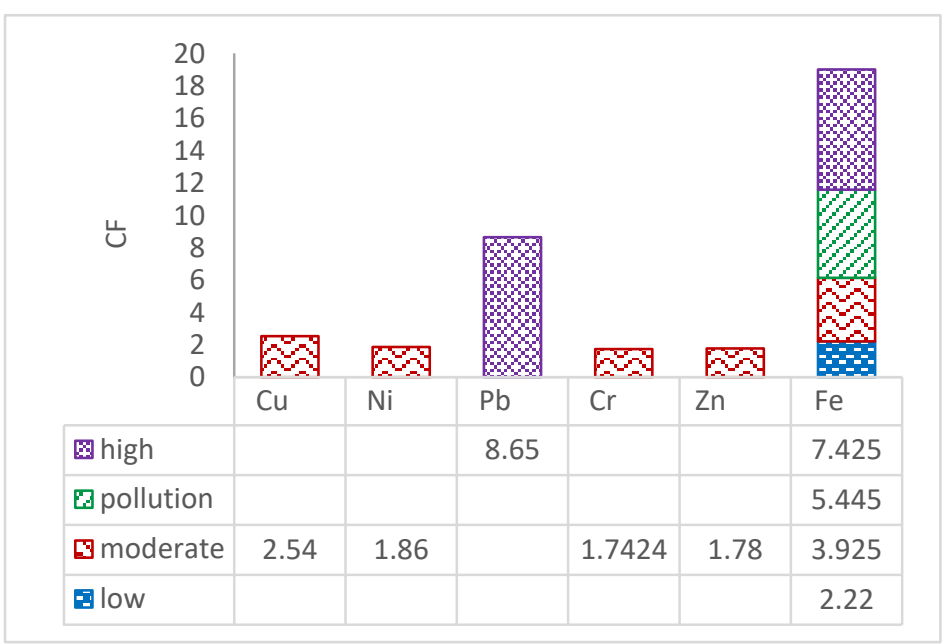

Figure 2. The contamination factor $(\mathrm{CF})$ of trace metals in herbal plants 
Table 2. One- way ANOVA

\begin{tabular}{|c|c|c|c|c|c|}
\hline & Sum of Squares & $\mathrm{df}$ & Mean Square & $\mathrm{F}$ & Sig. \\
\hline Between Groups & 35818.050 & 5 & 7163.610 & 5.309 & 0.002 \\
\hline Within Groups & 31036.842 & 23 & 1349.428 & & \\
\hline Total & 66854.892 & 28 & & & \\
\hline
\end{tabular}

Table 3. Multiple Comparisons (Latin Square Design LSD) for a significance of trace element

\begin{tabular}{|c|c|c|c|c|c|c|}
\hline \multirow[t]{2}{*}{ (I) Metal } & \multirow[t]{2}{*}{ (J) Metal } & \multirow{2}{*}{$\begin{array}{l}\text { Mean Difference } \\
(\mathrm{I}-\mathrm{J})\end{array}$} & \multirow[b]{2}{*}{ Std. Error } & \multirow[b]{2}{*}{ Sig. } & \multicolumn{2}{|c|}{ 95\% Confidence Interval } \\
\hline & & & & & Lower Bound & Upper Bound \\
\hline \multirow[t]{5}{*}{$\mathrm{Fe}$} & $\mathrm{Zn}$ & 11.78000 & 23.23298 & 0.617 & -36.2811 & 59.8411 \\
\hline & $\mathrm{Cr}$ & $90.39000^{*}$ & 24.64229 & 0.001 & 39.4135 & 141.3665 \\
\hline & $-\mathrm{Pb}$ & $80.04000^{*}$ & 23.23298 & 0.002 & 31.9789 & 128.1011 \\
\hline & $\mathrm{Ni}$ & $74.34000^{*}$ & 23.23298 & 0.004 & 26.2789 & 122.4011 \\
\hline & $\mathrm{Cu}$ & $71.76000^{*}$ & 23.23298 & 0.005 & 23.6989 & 119.8211 \\
\hline \multirow[t]{5}{*}{$\mathrm{Zn}$} & $\mathrm{Fe}$ & -11.78000 & 23.23298 & 0.617 & -59.8411 & 36.2811 \\
\hline & $\mathrm{Cr}$ & $78.61000^{*}$ & 24.64229 & 0.004 & 27.6335 & 129.5865 \\
\hline & $-\mathrm{Pb}$ & $68.26000^{*}$ & 23.23298 & 0.007 & 20.1989 & 116.3211 \\
\hline & $\mathrm{Ni}$ & $62.56000^{*}$ & 23.23298 & 0.013 & 14.4989 & 110.6211 \\
\hline & $\mathrm{Cu}$ & $59.98000^{*}$ & 23.23298 & 0.017 & 11.9189 & 108.0411 \\
\hline \multirow[t]{5}{*}{$\mathrm{Cr}$} & $\mathrm{Fe}$ & $-90.39000^{*}$ & 24.64229 & 0.001 & -141.3665 & -39.4135 \\
\hline & $\mathrm{Zn}$ & $-78.61000^{*}$ & 24.64229 & 0.004 & -129.5865 & -27.6335 \\
\hline & $-\mathrm{Pb}$ & -10.35000 & 24.64229 & 0.678 & -61.3265 & 40.6265 \\
\hline & $\mathrm{Ni}$ & -16.05000 & 24.64229 & 0.521 & -67.0265 & 34.9265 \\
\hline & $\mathrm{Cu}$ & -18.63000 & 24.64229 & 0.457 & -69.6065 & 32.3465 \\
\hline \multirow[t]{5}{*}{$\mathrm{Pb}$} & $\mathrm{Fe}$ & $-80.04000^{*}$ & 23.23298 & 0.002 & -128.1011 & -31.9789 \\
\hline & $\mathrm{Zn}$ & $-68.26000^{*}$ & 23.23298 & 0.007 & -116.3211 & -20.1989 \\
\hline & $-\mathrm{Cr}$ & 10.35000 & 24.64229 & 0.678 & -40.6265 & 61.3265 \\
\hline & $\mathrm{Ni}$ & -5.70000 & 23.23298 & 0.808 & -53.7611 & 42.3611 \\
\hline & $\mathrm{Cu}$ & -8.28000 & 23.23298 & 0.725 & -56.3411 & 39.7811 \\
\hline \multirow[t]{5}{*}{$\mathrm{Ni}$} & $\mathrm{Fe}$ & $-74.34000^{*}$ & 23.23298 & 0.004 & -122.4011 & -26.2789 \\
\hline & $\mathrm{Zn}$ & $-62.56000^{*}$ & 23.23298 & 0.013 & -110.6211 & -14.4989 \\
\hline & $-\mathrm{Cr}$ & 16.05000 & 24.64229 & 0.521 & -34.9265 & 67.0265 \\
\hline & $\mathrm{Pb}$ & 5.70000 & 23.23298 & 0.808 & -42.3611 & 53.7611 \\
\hline & $\mathrm{Cu}$ & -2.58000 & 23.23298 & 0.913 & -50.6411 & 45.4811 \\
\hline \multirow[t]{5}{*}{$\mathrm{Cu}$} & $\mathrm{Fe}$ & $-71.76000^{*}$ & 23.23298 & 0.005 & -119.8211 & -23.6989 \\
\hline & $\mathrm{Zn}$ & $-59.98000^{*}$ & 23.23298 & 0.017 & -108.0411 & -11.9189 \\
\hline & $-\mathrm{Cr}$ & 18.63000 & 24.64229 & 0.457 & -32.3465 & 69.6065 \\
\hline & $\mathrm{Pb}$ & 8.28000 & 23.23298 & 0.725 & -39.7811 & 56.3411 \\
\hline & $\mathrm{Ni}$ & 2.58000 & 23.23298 & 0.913 & -45.4811 & 50.6411 \\
\hline
\end{tabular}

*The mean differences, which are significant at 0.05 level appear in bold.

Trace metals have been found in herbal plants in China, Pakistan, UAE, Saudi Arabia and other Middle East countries (Ernst, 2002; Ulla et al., 2012; Begumi et al., 2017; Dghaim et al., 2015; Maghrabi, 2014; Abou-Arab and Abou Donia, 2000), respectivaly. Based on the result, suggesting that most of the herbal plants suffer from metal pollution might be due to the planting or the way of transportation. Therefore, various factors are contributing to trace metal contamination in herbal plants as a source of agricultural soils pollution, coming from the pesticides, fertilizers, water irrigation, industrial emissions, and atmospheric deposition from town wastes (Mousavi et al., 2014). On the other hand, trace metals contents varied depending on mother country, ecological contamination levels, and processing techniques (Abou-Arab and Abou Donia, 2000; Abu-Darwish, 2009).

The statistical results showed significant difference between group means as determined by one-way ANOVA $(\mathbf{F}(5,23)$ $=5.309, \mathbf{p}=0.002)$ Table 2 . Therefore, to detect the significant difference between them, the Post Hoc Tests was used, and the results are demonstrated in Table 3. These findings suggest that there was no significant difference between elements concentration examined in this investigation $(p>0.05)$. Although, there was a significant difference in the elements appearance in bold with value of $(\mathrm{p}<0.05)$ illustrated in Table 3. 


\section{Conclusions}

This examination demonstrated that the herbal plants may represent a significant contributor to the general population as a source of essential elements, such as $\mathrm{Fe}, \mathrm{Zn}$, and $\mathrm{Ni}$.On the other hand, some metals such as $\mathrm{Cu}, \mathrm{Ni}, \mathrm{Zn}$, and $\mathrm{Cr}$ are present at level higher than the permissible limits of metals set by WHO. Besides, the herbal plants were found to have a large amount of harmful metals, e.g. Pb. Therefore, more consideration should be taken into account to control and check pollution levels in herbal plants. Additionally, from this point considering an action for new study is desired to explore the contamination levels of the trace elements in herbal plants and their correlation with the soil, water irrigation, pesticides, and fertilizers

\section{Acknowledgments}

Special thanks to the chemistry department, faculty of science, king Abdulaziz University, Jeddah, Saudi Arabia for equipment's and the facilities, where this evaluation has been carried out.

\section{References}

Abou-Arab A. A. K., \& Abou, D. M. A. (2000). Heavy metals in Egyptian spices and medicinal plants and the effect of processing on their levels. Journal of Agricultural and Food Chemistry, 48(6), 2300-2304. https://doi.org/10.1021/jf990508p

Abu-Darwish, M. S, \& Abu-Dieyeh, Z. H. (2009). Essential oil content and heavy metals composition of Thymus vulgaris cultivated in various climatic regions of Jordan. Int. J. Agric. Biol., 11(1), 59-63.

AlBraik, F. A., Rutter, P. M., \& Brown, D. (2008). A cross-sectional survey of herbal remedy taking by United Arab Emirate (UAE) citizens in Abu Dhabi. Pharmacoepidemiology and drug safety. 17(7), 725-732. https://doi.org/10.1002/pds.1591

Al-Hammad, B. A., \& Abd El-Salam, M. M. (2016). Evaluation of heavy metal pollution in water wells and soil using common leafy green plant indicators in the Al-Kharj region, Saudi Arabia. Environ Monit Assess. 188, 324. https://doi.org/10.1007/s10661-016-5331-2

Ali Mohamed, H. H., \& Al-Qahtani, K. M. (2012). Assessment of some heavy metals in vegetables cereals and fruits in Saudi Arabian markets. The Egyptian Journal of Aquatic Research, 38(1), 31-37. https://doi.org/10.1016/j.ejar.2012.08.002

AL-Jaboobi, M., Zouahri, A., Tijane, M., El-Housni, A., Mennane, Z., \& Yachou, H. (2014). Evaluation of trace elements pollution in groundwater, soil and some vegetables irrigated with wastewater in the Skhirat region "Morocco". Journal of Materials and Environmental Science, 5(3), 961-966.

Altundag, H., \& Tuzen, M. (2011). Comparison of dry, wet and microwave digestion methods for the multi element determination in some dried fruit samples by ICP-OES. Food and Chemical Toxicology, 49(11), 2800-2807. https://doi.org/10.1016/j.fct.2011.07.064

Begumi, H. A., Hamayun, M., Zaman, K., Shinwari, Z. K., \& Hussain, A. (2017). Heavy Metal Analysis in Frequently Consumable Medicinal Plants of Khyber Paktunkhwa, Pakistan. Pak. J. Bot., 49(3), 1155-1160.

Dghaim, R., Al Khatib, S., Rasool, H., \& Ali Khan, M. (2015). Determination of heavy metals concentration in traditional herbs commonly consumed in the United Arab Emirates. Journal of Environmental and Public Health. 2015, 1-6. https://doi.org/10.1155/2015/973878

Ernst, E. (2002). Toxic heavy metals and undeclared drugs in Asian herbal medicines. Trends in Pharmacological Sciences, 23(3), 136-139. https://doi.org/10.1016/S0165-6147(00)01972-6

Fabricant, D. S., \& Farnsworth, N. R. (2001). The value of plants used in traditional medicine for drug discovery. Environmental Health Perspectives, 109(Suppl 1), 69-75. https://doi.org/10.1289/ehp.01109s169

Farago, M. E. (2008). Plants and the chemical elements: biochemistry, uptake, tolerance and toxicity: Plants as Indicators of Mineralisation and Pollution Ch 8 wiley online library:221.

Hakanson, L. (1980). An ecological risk index for aquatic pollution control. A sedimentological approach, Water Research, 14 (8), 975-1001. https://doi.org/10.1016/0043-1354(80)90143-8

Kananke, T., Wansapala, J., \& Gunaratne, A. (2014). Heavy Metal Contamination in Green Leafy Vegetables Collected from Selected Market Sites of Piliyandala Area, Colombo District, Sri Lanka. American Journal of Food Science and Technology, 2(5), 139-144. https://doi.org/10.12691/ajfst-2-5-1

Korfali, S. I., Mroueh, M., Al-Zein, M., \& Salem, R. (2013). Metal concentration in commonly used medicinal herbs and infusion by Lebanese population: health impact. Journal of Food Research, 2(2), 70-82. 
https://doi.org/10.5539/jfr.v2n2p70

Mahan, L. K., Escott-Stump, S., \& Raymond, J. L. (2017). Krause's food \& the nutrition care process $14^{\text {th }}$ Edition Elsevier Health Sciences.

Magaji, Y., Ajibade, G. A., Yilwa, V. Appah, M. Y. J., Haroun, A. A., Alhaji, I., Namadi, M. M., \& Sodimu, A. I. (2018). Concentration of heavy metals in the soil and translocation with phytoremediation potential by plant species in military shooting range. World Scientific News, 92(2), 260-271.

Maghrabi, I. A. (2014). Determination of some mineral and heavy metals in Saudi Arabia popular herbal drugs using modern techniques. African Journal of Pharmacy and Pharmacology, 8(36), 893-898. https://doi.org/10.5897/AJPP12.1455

Massadeh, A. M., \& Al-Massaedh, "Ayat Allah", T. (2018). Determination of heavy metals in canned fruits and vegetables sold in Jordan market. Environ Sci Pollut Res., 25, 1914-1920. https://doi.org/10.1007/s11356-017-0611-0

Mousavi, Z., Ziarati, P., Esmaeli, D. M., \& Qomi, M. (2014). Heavy metals (lead and cadmium) in some medicinal herbal products in Iranian Market. Iranian Journal of Toxicology, 8(24), 1004-10.

Nouri, M., \& Haddioui A. (2016). Assessment of metals contamination and ecological risk in Ait Ammar abandoned Iron mine soil, Morocco, Ekologia (Bratislava). The Journal of Institute of Landscape Ecology of Slovak Academy of Scineces, 35 (1), 32-49. https://doi.org/10.4172/2161-0525.1000334

Ogundele, D., Adio, A., \& Oludele, O. (2015). Heavy Metal Concentrations in Plants and Soil along Heavy Traffic Roads in North Central Nigeria. Journal of Environmental \& Analytical Toxicology, 5(6), 1-5. DOI.10.4172/2161-0525.1000334.

Onder, S., Dursun, S., Gezgin, S., \& Demirbas, A. (2007). Determination of heavy metal pollution in grass and soil of city centre green areas (Konya, Turkey). Polish Journal of Environmental Studies, 16(1), 145-154.

Pandolfini, T., Gremigni, P., Gabbrielli, R., Pankhurst, C., Doube, B., \& Gupta, V. (1997). Biomonitoring of soil health by plants. Biological indicators of soil health. CABI UK:325-347.

Rascio, N., \& Navari-Izzo, F. (2011). Heavy metal hyperaccumulating plants: How and why do they do it? And what makes them so interesting? Plant Science, 180(2), 169-181. https://doi.org/10.1016/j.plantsci.2010.08.016

Saad, B., Azaizeh, H., Abu-Hijleh, G., \& Said, O. (2006). Safety of traditional Arab herbal medicine. Evid. Based Complement Alternat Med., 3(4), 433-439. https://doi.org/10.1093/ecam/nel058

Singh, R., Gautam, N., Mishra, A., \& Gupta, R. (2011). Heavy metals and living systems: An overview. Indian Journal of Pharmacology, 43(3), 246-253. https://doi.org/10.4103/0253-7613.81505

Suciu, I., Cosma, C., Todică, M., Bolboacă, S. D., \& Jäntschi, L. (2008). Analysis of soil heavy metal pollution and pattern in Central Transylvania. International Journal of Molecular Sciences, 9(4), 434-453. https://doi.org/10.3390/ijms9040434

Ulla, R., Khader, J. A., Hussain, I., Abd, E. N. M., Talha, M., \& Khan, N. (2012). Investigation of macro and micro-nutrients in selected medicinal plants, African Journal of Pharmacy and Pharmacology, 6(25), 1829-1832.

Wang, J., Bai, J. H., Gao, Z. Q., Lu, Q. Q., \& Zhao, Q. Q. (2015). Soil As Levels and Bioaccumulation in Suaeda salsa and Phragmites australis Wetlands of the Yellow River Estuary, China. BioMed Research International. 2015 Article ID 301898, 1-7. DOI.org/10.1155/2015/301898.

Wheal, M. S., Fowles, T. O., \& Palmer, L. T. (2011). A cost-effective acid digestion method using closed polypropylene tubes for inductively coupled plasma optical emission spectrometry (ICP-OES) analysis of plant essential elements. Analytical Methods, 3(12), 2854-63. https://doi.org/10.1039/c1ay05430a

World Health Organization (WHO), (2011). Traditional Medicine Strategy, World Health Organization, Geneva, Switzerland.

\section{Copyrights}

Copyright for this article is retained by the author(s), with first publication rights granted to the journal.

This is an open-access article distributed under the terms and conditions of the Creative Commons Attribution license (http://creativecommons.org/licenses/by/4.0/). 